\title{
Justice Rehnquist's Theory of Property
}

Commentators have noted two significant characteristics of the Burger Court: the continuing influence of Justice Rehnquist ${ }^{1}$ and the increasing respect accorded to rights in private property. ${ }^{2}$ This Note connects these two trends by investigating Rehnquist's views on property. ${ }^{3}$ While Rehnquist has expanded protection for traditional property rights, he has narrowed the scope and protection of rights in the "new property." Although he did not create the doctrine that different forms of property are entitled to different levels of constitutional protection, ${ }^{5}$ Rehnquist bears primary responsibility for the form that doctrine has assumed in the Burger Court.

Section I of the Note sets forth the Court's analysis of constitutional property rights. Section II argues that, depending on whether the case involves traditional or new forms of property, Rehnquist uses different standards to determine whether a protected property interest exists, what its dimensions are, and what level of constitutional protection it deserves. These differences in treatment are compatible with what some economists

1. See, e.g., Fiss \& Krauthammer, The Rehnquist Court, New Republic, Mar. 10, 1982, at 14 (Rehnquist provides Burger Court's vision); Frank, The Burger Court-The First Ten Years, LAw \& Conremp. ProBs., Summer 1980, at 101, 125 (Rehnquist philosopher of Burger Court); Powell, The Compleat Jeffersonian: Justice Rehnquist and Federalism, 91 YALE. L.J. 1317, 1318-19 (1982) (Rehnquist's authorship of important opinions testifies to significant influence on colleagues); Shapiro, Mr. Justice Rehnquist: A Preliminary View, 90 HaRv. L. Rev. 293, 293 (1976) (importance of Rehnquist's early opinions justifies preliminary consideration of his work).

2. See Oakes, "Property Rights" in Constitutional Analysis Today, 56 Wash. L. Rev. 583, 596-97 (1981) (Court entering phase in which it will again give property rights substantive constitutional content); Van Alstyne, The Recrudescence of Property Rights as the Foremost Principle of Civil Liberties: The First Decade of the Burger Court, Law \& ConTEMP. ProBs., Summer 1980, at 66, 70 (re-emergence of property rights marks Supreme Court's "liberty" decisions during 1970's).

3. Several commentators have noted the significance Rehnquist attributes to property rights. See Fiss \& Krauthammer, supra note 1, at 21 (Rehnquist uses state autonomy to promote property); Lind, Justice Rehnquist: First Amendment Speech in the Labor Context, 8 Hastings Const. L.Q. 93, 120 (1980) (Rehnquist prefers property rights over First Amendment rights). In contrast to this Note, however, these articles do not discuss Rehnquist's views on the creation of property interests, distinguish his treatments of what the Note calls "due process property" and "just compensation property," or place his views on property within a larger perspective.

4. See Reich, The New Property, 73 Yale L.J. 733 (1964) (government largess important new form of property).

5. The Warren Court established a fundamental difference in treatment in Flemming v. Nestor, 363 U.S. 603 (1960). In upholding the constitutionality of a statute denying Social Security benefits to certain deported aliens, the Court held that such benefits were not "accrued property rights." Id. at 608-11. Since they were mere entitlements, Congress could withdraw these benefits without giving compensation, provided that its action satisfied a weak rational relation test. Id. at 611-12.

The Court has never adequately explained the basis for its fundamentally different treatment of "accrued property rights" as opposed to "entitlements." In United States R.R. Retirement Bd. v. Fritz, 449 U.S. 166 (1980), Rehnquist wrote for the majority: "There is no claim here that Congress has taken property in violation of the Fifth Amendment, since railroad benefits, like Social Security benefits, are not contractual and may be altered or even eliminated at any time." Id. at 174. Rehnquist does not explain why the fact that benefits such as Social Security are not "contractual" is alone sufficient to show that they may be altered or eliminated at any time. 
and legal theorists regard as an efficient distribution of property rights. The Note concludes in Section III that Rehnquist's theory of property gives constitutional significance to this particular social theory and its set of assumptions.

\section{The Analysis of Property}

The Constitution protects property under the due process ${ }^{6}$ and just compensation ${ }^{7}$ clauses. Although they appear different in scope and purpose, each clause requires that a court address closely analogous questions. A court must first ascertain the existence and nature of the underlying property interest and then determine whether the government's action with respect to that property interest has violated constitutional requirements.

The Court frames the question of whether a protected property interest exists as one concerning the reasonableness of the property holder's expectations, ${ }^{8}$ an issue that must be decided by reference to some independent source, such as state law. ${ }^{2}$ Although this view of the creation of property interests applies to property protected under both the due process and the just compensation clauses, ${ }^{10}$ some kinds of property are protected solely by the due process clause while others enjoy the additional protections of the just compensation clause. ${ }^{11}$

6. U.S. CoNST. amend. V ("No person shall be ... deprived of . . property, without due process of law . . . ."); id. amend. XIV, § 1 ("nor shall any State deprive any person of . . . property, without due process of law").

7. U.S. ConST. amend. V ("nor shall private property be taken for public use, without just compensation"). The just compensation clause was made applicable to the states through the Fourteenth Amendment in Chicago, B. \& Q.R.R. v. Chicago, 166 U.S. 226, 239 (1897).

8. While the Court will not treat "unilateral" expectations as property interests, see Board of Regents v. Roth, 408 U.S. 564, 577 (1972), it does consider "reasonable" expectations to be property, see Penn Cent. Transp. Co. v. New York City, 438 U.S. 104, 124-25 (1978) (interests must be sufficiently bound with claimant's "reasonable expectations" to constitute "property"). The connections the Court draws between property interests and the reasonableness of a party's expectations can easily lead to circularity in analysis. It may seem natural, in determining whether there is a property interest, to inquire into the reasonableness of the party's expectations. But the circle is drawn if one then answers the reasonableness question by determining whether the expectations are grounded in property interests recognized by some independent source such as state law. See infra note 9.

9. Shortly after Rehnquist joined the Supreme Court in January 1972, C. BARNES, MEN OF THE Supreme Court 127 (1978), Justice Stewart set forth what the Court has adopted as its paradigmatic statement on property:

Property interests, of course, are not created by the Constitution. Rather, they are created and

their dimensions are defined by existing rules or understandings that stem from an indepen-

dent source such as state law-rules or understandings that support certain benefits and that

support claims of entitlement to those benefits.

Board of Regents v. Roth, 408 U.S. 564, 577 (1972).

10. The Court cites Stewart's account of the creation of property interests from Roth, which involved a due process claim, in discussing property interests in cases involving the just compensation clause. E.g., Texaco, Inc. v. Short, 454 U.S. 516, 525 (1982); Webb's Fabulous Pharmacies, Inc. v. Beckwith, 449 U.S. 155, 161 (1980).

11. See supra note 5 . 


\section{A. Due Process Property}

In this century, the Supreme Court has construed the due process clause to protect many different forms of property and to provide both substantive and procedural protections. ${ }^{12}$ Goldberg $v$. Kelly ${ }^{13}$ began the "due process revolution," 14 in which courts extended due process protection to a variety of interests not recognized by the common law. ${ }^{15}$ The Court soon made clear, however, that it would define these interests not through constitutional interpretation but through examination of "an independent source such as state law."16

In the procedural due process cases that the Court has decided since Goldberg, the interests it treats as property fall into three categories: (1) entitlements based on the fulfillment of criteria under which the government provides a benefit; ${ }^{17}(2)$ entitlements based on the inapplicability of the exclusive conditions under which the government may deprive the beneficiary of the benefit, ${ }^{18}$ and (3) substantial property interests based on traditional criteria of ownership. ${ }^{10}$ While property of the third type is

12. The Court has invoked the due process clause to extend substantive protection against legislative encroachment to economic interests, such as the right of the employer and employee to contract. See Lochner v. New York, 198 U.S. 45 (1905) (invalidating New York's 60-hour limit on bakery employees' work week on grounds that it was an undue invasion of the right of employers and employees to contract); see also L. TRIBE, AMERICAN Constitutional LAw $\S \S 8-2$ to 8-7, at 434-42 (1978) (discussing Court's substantive due process protection of economic interests during "Lochner era," lasting from 1897 to 1937). Even after the Court retreated from providing substantive due process protection, it continued to extend procedural due process protection to property interests of the sort recognized at common law. See, e.g., Ewing v. Mytinger \& Casselberry, Inc. 339 U.S. 594, 599 (1950) (application of due process to seizure of misbranded articles requires "that there is at some stage an opportunity for a hearing and a judicial determination"); Mullane v. Central Hanover Bank \& Trust Co., 339 U.S. 306 (1950) (due process requires that beneficiary of a pooled trust be given opportunity to participate in control of his property).

13. 397 U.S. 254 (1970).

14. S. Breyer \& R. Stewart, Administrative Law and Regulatory Policy 594 (1979).

15. Prior to Goldberg, the Court did not extend full procedural due process protection to benefits provided by the government but not recognized by the common law, such as public employment or education. See Cafeteria \& Rest. Workers v. McElroy, 367 U.S. 886 (1961) (no violation of due process in commanding officer's summarily denying former employee access to site of former employment); Bailey v. Richardson, 182 F.2d 46, 57 (D.C. Cir. 1950), aff'd by an equally divided Court, 341 U.S. 918 (1951) (due process protections not applicable to dismissals from federal civil service). See generally S. BREYER \& R. STEWART, supra note 14, at 593-94 (pre-Goldberg traditional model of administrative law protected only interests recognized by common law).

16. Board of Regents v. Roth, 408 U.S. 564, 577 (1972). Several commentators have noted the change that began with Roth, in which the Court insisted that property rights be grounded in some extra-constitutional source such as state law. See, e.g., Monaghan, Of "Liberty" and "Property", 62 Cornel. L. Rev. 405, 409 (1977); Terrell, "Property," "Due Process," and the Distinction Between Definition and Theory in Legal Analysis, 70 GEO. L.J. 861, 884 (1982).

17. See Mathews v. Eldridge, 424 U.S. 319 (1976) (Social Security disability benefit payments).

18. See, e.g., Bishop v. Wood, 426 U.S. 341, 344-47 (1976) (no property interest because ordinance on which petitioner relied did not specify exclusive conditions under which he could be deprived of job); Arnett v. Kennedy, 416 U.S. 134, 140, 151-52 (1974) (property interest based on provision that federal civil servant may be removed or suspended only "for cause").

19. See Parratt v. Taylor, 451 U.S. 527 (1981) (hobby kit that prisoner had ordered through the mail). Cases in this category often involve creditors contemplating legal action against defaulting debt- 
protected by both the due process and the just compensation clauses, property of the first two types is protected only by the due process clause. ${ }^{20}$ The Note will therefore refer to property in the first two categories as "due process property" and to property in the third category as "just compensation property."

In a due process case, the claimant alleges that he has been deprived of a protected property interest without adequate procedural safeguards. The dispute may be over whether there is an underlying entitlement on which the claimant can rely ${ }^{21}$ or whether the process provided ensures that no claimant is unfairly deprived of any benefit to which he is entitled. ${ }^{22}$

\section{B. Just Compensation Property}

The just compensation clause prevents the government from taking private property without providing just compensation. ${ }^{23}$ The Court treats as "just compensation property" only common law property, ${ }^{24}$ such as realty

ors where creditors wish to gain control over some of the debtor's property pending final judgment. See, e.g., Fuentes v. Shevin, 407 U.S. 67 (1972) (creditor's writ of replevin); Sniadach v. Family Fin. Corp., 395 U.S. 337 (1969) (creditor's wage garnishment proceeding). Breyer and Stewart note that in such cases "[t]he Court has consistently recognized the interest of the debtor in retaining possession of funds or goods as 'property' for purposes of the due process clause." S. BREYER \& R. STEWART, supra note 14 , at 688 n.97.

20. See supra note 5. The first two categories are discussed in Note, Statutory Entillement and the Concept of Property, 86 YALE L.J. 695, 696-98 (1977). With respect to property of the third type, a debtor or creditor able to perfect title would have a property right based on traditional common law criteria and could thus claim just compensation if the government attempted to take his property. Other rights besides the protection of the just compensation clause are denied to holders of due process property. Welfare recipients, for example, cannot transfer their property rights to others. $C f$. Honoré, Ownership, in OXFORD Essays IN JuRISPRUDENCE 107, 120-21 (A. Guest ed. 1961) (right to transfer property part of "liberal" concept of "full" individual ownership). Recent cases suggest that the Court will characterize interests created by state law but not falling within traditional common law categories as "property" only if the state may remove them only "for cause." See Logan v. Zimmerman Brush Co., 455 U.S. 422,430 (1982); Memphis Light, Gas \& Water Div. v. Craft, 436 U.S. 1, 11-12 (1978); Bishop v. Wood, 426 U.S. 341,345 n.8 (1976). Since holders of the new property lack some of the traditional incidents of ownership, the Court is developing the view that the central incident of ownership of the new property is the right not to be deprived of that property except "for cause."

21. See, e.g., Bishop v. Wood, 426 U.S. 341, 343-47 (1976) (plaintiff has not established property interest in job necessary to give him right to hearing before dismissal); Perry v. Sindermann, 408 U.S. 593, 599 (1972) (plaintiff must show property interest in job at state university to have right to hearing before dismissal).

22. The Court in Mathews v. Eldridge, 424 U.S. 319 (1976), emphasized the importance of determining whether the process provided was likely to result in an erroneous deprivation of a protected interest and the probable value of additional or substitute procedures. Id. at 335. Commentators have criticized the Court's valuing procedural safeguards primarily in terms of their contribution to accuracy. See, e.g., L. TRIBE, supra note $12, \S 10-13$, at 542-43 (Court's unwillingness to consider values beyond accuracy of result represents abdication of judicial responsibility under due process clauses); Mashaw, Administrative Due Process: The Quest for a Dignitary Theory, 61 B.U.L. REv. 885, 895-96 (1981) (Court needs a broadened, non-instrumentalist perspective on due process).

23. See supra note 7.

24. Though just compensation property often has deep roots in the common law, courts nevertheless require that an owner seeking compensation establish that state law recognizes his claim to the property he alleges has been taken. See Annot., 1 A.L.R. FED. 479, 482 (1969) (courts refer to state 
and personalty, ${ }^{25}$ and its ancillary forms, such as statutory liens and the right to interest on an interpleader fund. ${ }^{28}$

Unlike due process, claims under the just compensation clause do not always involve a dispute over the entitlement to, or ownership of, property. When private loss and governmental involvement are clear, the disputed issue is whether the loss that the government has inflicted amounts to a "taking" for which it must pay compensation. ${ }^{27}$ Many just compensation cases do, however, involve disputes over the precise nature of the underlying property right. ${ }^{28}$ In such cases, the claimant must establish that prior law had created reasonable expectations that the contested action defeated. ${ }^{20}$

\section{Justice Rehnquist's Differential Treatment of Due Process Property and Just Compensation Property}

Justice Rehnquist's acceptance of Justice Stewart's proposition that property interests are not created by the Constitution but by an independent source, such as state law, ${ }^{30}$ suggests that his analysis of property interests would not depend upon the clause under which a claim against

law to define "property" in condemnation proceedings by United States).

25. See Andrus v. Allard, 444 U.S. 51 (1979) (Indian artifacts); Penn Cent. Transp. Co. v. New York City, 438 U.S. 104 (1978) (Penn Central's right to use its land to build office building).

26. See United States v. Security Indus. Bank, 103 S. Ct. 407 (1982) (statutorily created lien); Webb's Fabulous Pharmacies, Inc. v. Beckwith, 449 U.S. 155 (1980) (right to interest on an interpleader fund).

27. Difficulties arise when the government has diminished, rather than wholly appropriated, the value of a clearly defined property right. See, e.g., Goldblatt v. Hempstead, 369 U.S. 590, 592 (1962) (fact that government activity has diminished value of property not sufficient to show "taking"); United States v. Central Eureka Mining Co., 357 U.S. 155, 168 (1958) (fact that governmental regulation has deprived owner of most profitable use of property not sufficient to show "taking"). The question is whether the costs of the activity should be borne by the government or a few persons. See Michelman, Property, Utility, and Fairness: Comments on the Ethical Foundations of "Just Compensation" Law, 80 Harv. L. Rev. 1165, 1165 (1967).

28. See, e.g., United States v. Willow River Power Co., 324 U.S. 499, 502-03 (1945) (dispute over whether head of waterway affected by government activity, in which plaintiff has economic interest, amounts to property right); United States ex rel. Tennessee Valley Auth. v. Powelson, 319 U.S. 266, 275-76 (1943) (dispute over whether state's grant of power of eminent domain to private party constitutes property).

29. See, e.g., United States v. Willow River Power Co., 324 U.S. at 511 (plaintiff not entitled to compensation for loss of high-water level of river where interest not protected property); United States ex rel. Tennessee Valley Auth. v. Powelson, 319 U.S. at 276 (plaintiff not entitled to compensation for loss of power of eminent domain since state's grant of power is mere revocable privilege).

30. Rehnquist cites Stewart's proposition as authority in a number of cases. See, e.g., Parratt v. Taylor, 451 U.S. 527, 529 n.1 (1981) (Rehnquist, J.) (quoting Board of Regents v. Roth, 408 U.S. 564, 577 (1972)); Arnett v. Kennedy, 416 U.S. 134, 151 (1974) (plurality opinion) (Rehnquist, J.) (same). Rehnquist emphasizes that state governments, not the federal government, have the primary authority to define property. See PruneYard Shopping Center v. Robins, 447 U.S. 74, 84 (1980) (Rehnquist, J.) ("Nor as a general proposition is the United States, as opposed to the several States, possessed of residual authority that enables it to define 'property' in the first instance."); Oregon $e x$ rel. State Land Bd. v. Corvallis Sand \& Gravel Co., 429 U.S. 363, 378 (1977) (Rehnquist, J.) (property ownership in federal system governed by state law, not general federal law). 
governmental deprivation arises. Nevertheless, Rehnquist's treatment of particular cases reveals important differences in his methods of determining the presence of property interests, their dimensions, and the extent to which the Constitution protects their holders against government interference. $^{31}$

\section{A. The Existence and Dimensions of Protected Property Interests}

Only in just compensation cases does Rehnquist consider any sources or circumstances beyond positive state law to determine that the plaintiff's expectations were reasonable, and therefore that a protected property interest exists. ${ }^{32}$ Having found a property interest, Rehnquist is more inclined to hold that property protected under the due process clause is qualified by some other provision of state law than he is to find that property protected under the just compensation clause is similarly qualified.

\section{Determining the Existence of Property Interests}

In Kaiser Aetna v. United States, ${ }^{38}$ Justice Rehnquist maintained that the United States' attempt to compel a right of public access to Kuapa Pond, which had been rendered navigable by its lessees, Kaiser Aetna, was a compensable taking. ${ }^{34}$ While noting that the pond was private property under the relevant state law, Rehnquist implicitly recognized that this state law claim was insufficient to establish the property interest that must underlie a claim of uncompensated taking. ${ }^{36}$ Instead of denying the existence of a property interest, Rehnquist broadened the scope of the

31. The court must find "state action" before the constitutional guarantees of due process or just compensation are implicated. Rehnquist has narrowed the state action doctrine in due process contexts. See, e.g., Blum v. Yaretsky, 457 U.S. 991 (1982) (Rehnquist, J.) (no state action in nursing homes' decision to discharge or transfer Medicaid patients to lower levels of care); Flagg Bros. v. Brooks, 436 U.S. 149 (1978) (Rehnquist, J.) (no state action in storage company's invoking statesanctioned self-help remedies); Jackson v. Metropolitan Edison Co., 419 U.S. 345 (1974) (Rehnquist, J.) (no state action in privately owned and operated utility company's termination of petitioner's electric service, despite fact that utility was heavily regulated and had partial monopoly).

32. Rehnquist does not always look beyond state positive law to discover a protected property interest in a just compensation context. For a consistent application of the view that state positive law defines property, see Texaco, Inc. v. Short, 454 U.S. 516 (1982) (Stevens, J.) (joined by Rehnquist, J.) (upholding Indiana law providing for lapse of mineral owners' property interests).

33. 444 U.S. 164 (1979) (Rehnquist, J.)

34. Id. at 178 .

35. Previous cases had established that the doctrine of "navigational servitude," which allows the United States to regulate navigable waters without compensating those affected, applied to waters navigable in their natural condition. See, e.g., United States v. Rands, 389 U.S. 121 (1967); United States v. Willow River Power Co., 324 U.S. 499 (1945); United States v. Chicago, M., St. P. \& P.R.R., 312 U.S. 592 (1941). The question in Kaiser Aetna, however, was whether the servitude applied to waters made navigable by private effort. 444 U.S. at 174-78. The correctness of Kaiser Aetna's expectation of a property interest was therefore uncertain even though Hawaii had long treated fishponds as private property. $I d$. at $165,166,179$. 
inquiry and found that Kaiser Aetna's expectations that the pond would remain private were reasonable. ${ }^{38}$

Rehnquist noted, first, that Kaiser Aetna had relied on the Army Corps of Engineers' advice that Kaiser Aetna did not need a permit to proceed with its developments and operations in Kuapa Pond. ${ }^{37}$ Rehnquist cited no finding that Kaiser Aetna actually relied on the Corps' advice, however, or that the Corps had consented to anything beyond Kaiser Aetna's continuing with its dredging operations. Even if the Corps had affirmatively consented to the dredging of the channel, ${ }^{38}$ such consent would seem relevant only to the question of whether Kaiser Aetna needed a permit, not to the reasonableness of its expectations that the pond would remain private once it was navigable. ${ }^{39}$

Rehnquist also emphasized that Kaiser Aetna itself had dredged the channel, investing "substantial amounts of money in making improvements." 40 This may show that Kaiser Aetna believed its expectations of continued private ownership were reasonable. Given the attenuated nature of the consent involved, however, it does not show that the expectations were reasonable in the more objective sense necessary to establish a protected property interest. ${ }^{41}$

Rehnquist observed, finally, that the government had interfered with the right to exclude, a right "universally held" to be fundamental. ${ }^{12}$ This

36. Rehnquist was careful to refrain from treating any particular factor as dispositive. 444 U.S. at 178 n.9.

37. 444 U.S. at 179; see also id. at 167. Rehnquist describes the "consent" as acquiescence in Kaiser Aetna's proposals to dredge the channel (thereby connecting the pond to Manalua Bay and the Pacific Ocean) and to increase the clearance between a bridge constructed along the barrier beach and the sea. Id. at 167.

38. The extent to which the Corps affirmatively consented was disputed. The Supreme Court, 1979 Tern, 94 HaRv. L. REv. 75, 208 n.23 (1980).

39. The Court emphasized "mutually explicit understandings" in establishing the standard for such non-statutory, non-contractual agreements to create reasonable expectations amounting to property interests for due process purposes. See Perry v. Sindermann, 408 U.S. 593, 601 (1972) (Stewart, J.) (joined by Rehnquist, J.). In Jago v. Van Guren, 454 U.S. 14, 17-20 (1981) (per curiam) (including Rehnquist, J.), the Court argued that the Sindermann Court relied on two analogous doctrines to give content to the notion of "mutually explicit understandings": implied contract and the common law of an industry or plant. The second is clearly inapplicable to Kaiser Aetna. As for the first, Rehnquist refers to no finding that the Corps understood that consent to Kaiser Aetna's dredging the channel was consent to allowing the pond to remain private. The fact that Rehnquist even mentions reliance on the Corps' advice shows the extent to which he is willing, in a just compensation context involving a great deal of money, to give weight to a wide range of circumstances underlying a party's expectations.

40. 444 U.S. at 176. Rehnquist's characterization of Kaiser Aetna in PruneYard Shopping Center v. Robins, 447 U.S. 74 (1980) (Rehnquist, J.), stressed the importance to the outcome in Kaiser Aetna of the fact that the government had interfered with Kaiser Aetna's "reasonable investmentbacked expectations." 447 U.S. at 84.

41. See supra note 39 .

42. 444 U.S. at 179; cf. infra note 95 (discussing legal and economic theorists who argue for efficiency of allowing exclusion). But see Honore, supra note 20 , at 113 (omitting "right to exclude" from standard incidents of ownership and criticizing accounts of property which focus on exclusion). 
assertion suggests a concept of property defined by its universality, a position inconsistent with Rehnquist's usual insistence that property claims must be established by reference to positive state law. ${ }^{43}$

Rehnquist's capacious positivism in Kaiser Aetna contrasts markedly with the niggardly positivism of the Court's due process analysis in Bishop v. Wood." The Court held that a policeman classified as a "permanent employee" by a city ordinance did not have a property interest in his job and therefore was not entitled to a hearing before being dismissed. ${ }^{\text {ts }}$ Bishop stressed his reliance on his classification as a permanent employee and on the long and continuous employment of several other officers, arguing that these factors rendered his expectation of continued employment reasonable. ${ }^{48}$ Despite the similarity between Bishop's assertions ${ }^{47}$ and the claims of reliance in Kaiser Aetna, ${ }^{48}$ the Bishop court made no inquiry into whether Bishop's employment situation rendered his expectation of continued employment reasonable. ${ }^{40}$

The holder of just compensation property clearly benefits from Rehn-

43. See supra note 30 .

44. 426 U.S. 341 (1976) (Stevens, J.) (joined by Rehnquist, J.). The dissenting Justices treated the majority opinion as adopting the analysis of Rehnquist's plurality opinion in Amett v. Kennedy, 416 U.S. 134 (1974). Bishop, 426 U.S. at 353 n.4 (Brennan, J., dissenting); id. at 355 (White, J., dissenting); id. at 361 (Blackmun, J., dissenting).

45. 426 U.S. at 347.

46. The district court stated that the petitioner "contends that after . . . six months probation ... he became a permanent employee, and that several police officers have been employed by the city on a continued basis for many years, and that he therefore acquired tenure or at least acquired the right to expect continued employment." 377 F. Supp. 501, 503 (W.D. N.C. 1973); see also 426 U.S. at 354 n.5 (Brennan, J., dissenting) ("As to respondents' personnel practices, it is important to note that in a department which currently employs 17 persons, petitioner's was the only discharge, for cause or otherwise, during the period of over three years from the time of his hiring until the time of pretrial discovery.").

47. The district court judge began his analysis of Bishop's claims by stating the law in North Carolina as he understood it: "Under the law in North Carolina, nothing else appearing, a contract of employment which contains no provision for the duration or termination of employment is terminable at the will of either party irrespective of the quality of performance by the other party." 377 F. Supp. at 504 (emphasis added). The judge interpreted the ordinance not to require notice or a hearing prior to dismissal and concluded that both the city ordinance and state law had been obeyed. Id. In reaching this conclusion, the judge ignored the feature of the law of North Carolina-the "nothing else appearing" clause-that presumably permitted a plaintiff to introduce evidence, beyond explicit contractual terms, which would qualify the presumptively "at will" nature of his employment. One may doubt the sufficiency of the evidence Bishop introduced to establish that his expectations of continued employment were reasonable, but this evidence appears not to have been seriously considered by the Supreme Court, which relied on the district court's uncritical conclusions. 426 U.S. at 347.

48. See supra p. 547.

49. Rehnquist's position in Bishop is not atypical. He has joined opinions in other due process clause cases focusing on the precise terms of statutory provisions or court rules to defeat a plaintiff's claim to a protected property interest. See, e.g., O'Bannon v. Town Court Nursing Center, 447 U.S. 773, 785-86 (1980) (Stevens, J.) (joined by Rehnquist, J.) (Medicaid provisions do not confer property interest in continued residence in nursing home of one's choice); Leis v. Flynt, 439 U.S. 438, 443 (1979) (per curiam) (including Rehnquist, J.) ("reasonable expectations of professional service" insufficient to establish property interest, given that state court rules leave authority to approve pro hac vice appearances to discretion of trial court). 


\section{Rehnquist and Property}

quist's attempt to shape a doctrine in which a court will consider a broad range of sources other than positive state law, and in particular the fact of substantial investment, in determining the reasonableness of the owner's expectations. Under such a doctrine the owner could more confidently invest in the property, knowing that if the government interferes with his "investment-backed expectations" a court is likely to find that these expectations were reasonable and that the government must pay compensation. By contrast, the holder of property protected only under the due process clause, such as a public employee, is well advised to study the subtleties of state court decisions. Under the doctrine Rehnquist espouses, a court will adopt a very narrow view of which factors render reasonable an expectation of continued receipt of the benefit, and is unlikely to find expectations arising out of the circumstances of employment to be reasonable.

\section{Determining the Dimensions of Property Interests}

Once the Court has found a protected property right, it must determine its dimensions. Rehnquist is more inclined to discover that some other provision of state law qualifies or limits the right in the context of due process than just compensation property.

In Goss v. Lopez, ${ }^{\text {so }}$ the majority found that Ohio law conferred on students a property right in obtaining a public education. ${ }^{51}$ Rehnquist joined in the dissent, which argued that even if sections of the Ohio code could be read to confer a property right, the right thereby conferred was qualified by another section of the code allowing principals to suspend students for up to ten days. ${ }^{52}$ The students had therefore not been deprived of any right actually conferred on them by Ohio law. ${ }^{\text {ss }}$

Yet, in the context of a just compensation claim in PruneYard Shopping Center $v$. Robins, ${ }^{\text {s4 }}$ Rehnquist failed to fully acknowledge that the property interest involved was limited by state constitutional law. PruneYard, a privately owned shopping center, had denied access to high

50. 419 U.S. 565 (1975) (White, J.)

51. Id. at 572-76. Therefore, the Court concluded, the state could not deprive them of that interest, even for a ten-day suspension, without the minimum procedures required by due process. Id.

52. 419 U.S. at 586-87 (Powell, J., dissenting) (joined by Rehnquist, J.)

53. Id. at 587 (Powell, J., dissenting) (joined by Rehnquist, J.) ("The Court . . disregards the basic structure of Ohio law in posturing this case as if Ohio had conferred an unqualified right to education."). The dissent also argued that even if there had been a deprivation of a protected property interest, the deprivation was so de minimis that it did not deserve protection under the due process clause. $I d$. at 587-89.

54. 447 U.S. 74, 82-84 (1980) (Rehnquist, J.). PruneYard also claimed that Lloyd Corp. v. Tanner, 407 U.S. 551 (1972), prevented a state from interpreting its constitution to confer more expansive individual liberties than those conferred by the U.S. Constitution, id. at 80 , that it had been deprived of its property without due process of law, 447 U.S. at 84, and that its own first amendment rights had been violated, $i d$. at 85 . 
school students who wished to solicit opposition to a United Nations resolution. ${ }^{\text {ss }}$

The California Supreme Court held that the California Constitution entitled the students to conduct their activity on PruneYard's property. ${ }^{58}$ Because PruneYard held its property subject to the California Constitution, and because that constitution gave expansive protection to speech, the state's requirement of access did not infringe PruneYard's property rights. ${ }^{\text {s7 }}$

Although Rehnquist affirmed the California Supreme Court's judgment, he maintained that its decision effected a "literal," though not a constitutional, taking of one of the most essential sticks in the bundle of property rights, the right to exclude others. ${ }^{58}$ Rehnquist thereby implicitly denied that Galifornia's Constitution fully determined the dimensions of

55. 447 U.S. at 77.

56. Robins v. PruneYard Shopping Center, 23 Cal. 3d 899, 592 P.2d 341, 153 Cal. Rptr. 854 (1979), aff'd, 447 U.S. 74 (1980).

57. The California Supreme Court argued that although no California statute specifically provided that shopping center owners must provide public forums, its decisions had interpreted the amendment of the state constitution referring to freedom of speech as according it special protection. The court argued that its decision in PruneYard was therefore consistent with its past decisions recognizing rights of speech and petition on private property, which "testify to the strength of "liberty of speech' in this state." Id. at 908, 592 P.2d at 346, 153 Cal. Rptr. at 859. On the basis of the claim that shopping centers can provide a valuable forum for exercising the constitutionally protected rights of speech and petition, the court concluded that "sections 2 and 3 of article 1 of the California Constitution protect speech and petitioning, reasonably exercised, in shopping centers even when the centers are privately owned." Id. at 910, 592 P.2d at 347, 153 Cal. Rptr. at 860. The U.S. Supreme Court affirmed even though PruneYard's discussion of Lloyd, 447 U.S. at 80-81 (discussing Lloyd Corp. v. Tanner, 407 U.S. 551 (1972)), strongly suggests that a different outcome would be required if the California Constitution had accorded no more protection to speech than the U.S. Constitution.

58. 447 U.S. at 82-84. Powell, supra note 1, at 1362-63, argues that the "liberal" result in PruneYard shows that Rehnquist does not use his federalism principles simply to promote his presumably conservative views. While Rehnquist did not find a constitutional taking, his finding of a literal taking portends serious limits on the authority of state governments to expand individual rights at the expense of property rights. By finding a literal taking despite the reasoning of the California Supreme Court, Rehnquist lowered the threshold at which a taking will be found and thereby made it easier to find a taking of constitutional dimensions in some future case. Rehnquist's insistence that in PruneYard there had been no interference with the petitioner's "reasonable investment-backed expectations," and that the economic value of PruneYard's property had not been significantly impaired, 447 U.S. at 84, suggests that if state expansion of rights infringes on a property owner's right to a reasonable return on a substantial investment, Rehnquist will find a constitutional taking despite the state's own definition of property rights.

The apparently innocuous finding of a "literal taking" in PruneYard may have additional significance for future cases. Fiss and Krauthammer, supra note 1, at 16, observe that Rehnquist "places apparently inconsequential statements unobtrusively in one opinion, only to use them several opinions later-when he makes them seem of central importance to the earlier case and decisive to the case at hand." Compare supra note 36 (Rehnquist's statement in Kaiser Aetna that no single factor dispositive) with supra note 40 (Rehnquist's stressing in PruneYard that investment-backed expectations were important in Kaiser Aetna).

Rehnquist's view of the shopping center owner's rights in PruneYard suggests that he endorses a rule-bound positivism, which fails to acknowledge fully the way in which rules of law may be qualified by principles expressed in a constitution. Dworkin has forcefully criticized views of law which see it as including only rules, not principles. See R. DworkIN, The Model of Rules $I$, in Takinc RughTs SERIOUSLY 14 (1978). 
property interests under California law, since even a literal taking could be found only by failing to accord full weight to the California Supreme Court's claims about the role of the state constitution in defining property rights.

The logic of Rehnquist's PruneYard decision provides holders of just compensation property with additional security against governmental interference, since they can claim the full bundle of property rights conferred by certain sections of state law rather than the depleted bundle that might appear were the total structure of state law taken into account. The logic of the Goss dissent, by contrast, suggests that holders of due process property face the possibility that expectations which appear reasonable under one section of state law may be found unreasonable when the total structure of the law is considered.

\section{B. The Permissibility of Collapsing the Constitutional Question Into the Definition of Property}

Once the Court has found a property interest, it must consider the constitutional question whether the government has provided due process or has taken property without providing compensation. While Rehnquist permits government to define due process property to include only limited procedural protections and thus allows government to defeat constitutional claims to due process, there is evidence that he would not permit government to define just compensation property to include only a limited set of remedies and thus would not allow the government to defeat constitutional claims for just compensation.

Rehnquist's opinion in Arnett v. Kennedy ${ }^{50}$ held that Kennedy had a property interest in his job because the federal law under which he was employed provided that he could be dismissed only "for cause." theless, Rehnquist held that the interest was limited by statutory procedures that ensured that the "for cause" requirement was satisfied:"1 "[W]here the grant of a substantive right is inextricably intertwined with the limitations on the procedures which are to be employed in determining that right, a litigant in [Kennedy's] position . . . must take the bitter with the sweet." ${ }^{\text {"62 }}$ In effect, since the definition of Kennedy's property interest included the procedures necessary to deprive him of his job, the government had not deprived him of any property interest to which he was entitled. ${ }^{\text {ss }}$

59. 416 U.S. 134 (1974) (Rehnquist, J.) (plurality opinion).

60. Id. at 151-52.

61. Id. at 152.

62. Id. at 153-54.

63. This doctrine severely limits the significance of having a due process property interest, since it 


\section{Rehnquist's concurrence in San Diego Gas \& Electric v. San Diego ${ }^{64}$} indicates that he would not permit a state to define just compensation property in a way that would defeat a claim for monetary compensation. In San Diego Gas, the owners of a 214-acre parcel of unimproved land claimed that the city's rezoning of their land and its adoption of an open space plan had so deprived them of the use of the property as to have effected a taking. ${ }^{65}$ While Rehnquist concurred in the decision to dismiss the case for lack of a final judgment below, ${ }^{6 B}$ he indicated substantial agreement with Justice Brennan's dissent. ${ }^{\circ 7}$ Brennan rejected the California Supreme Court's analysis in Agins v. City of Tiburon, ${ }^{68}$ which limited a property owner's remedy for an ordinance that exceeds the police power authority to invalidation of the provision. ${ }^{69}$ Under Agins, owners would

permits the government to define that interest statutorily so that it has fewer constitutional protections. Largely for this reason, six Justices rejected Rehnquist's reasoning in Arnelt. Id. at 185 (White, $\mathrm{J}$., concurring in part and dissenting in part) ("While the State may define what is and what is not property, once having defined those rights the Constitution defines due process, and as I understand it six members of the Court are in agreement on this fundamental proposition."); id. at 166-67 (Powell, $\mathrm{J}$., concurring in part and concurring in the result in part) (joined by Blackmun, J.); id. at 211 (Marshall, J., dissenting) (joined by Douglas and Brennan, JJ.).

Since Arnett, the Court has acknowledged the right of states to place substantive limits on property interests created by state law, see Martinez v. California, 444 U.S. 277, 282 n.5 (1980) (Stevens, J.) (unanimous decision) (state's immunity defense arguably only aspect of state's definition of property interest involved in creation of tort cause of action), but a majority of the Court has rejected government attempts to limit court scrutiny of the adequacy of procedures by including procedural requirements as part of the definition of property. See, e.g., Logan v. Zimmerman Brush Co., 455 U.S. 422, 432 (1982) (Blackmun, J.) (state provision of procedures designed to protect property interests does not bar federal constitutional assessment of adequacy of procedures); Vitek v. Jones, 445 U.S. 480, 491 (1980) (White, J.) ("[M]inimum requirements [of due process] being a matter of federal law, they are not diminished by the fact that the State may have specified its own procedures that it may deem adequate for determining the preconditions to adverse official action."). Rehnquist has disagreed. See Logan v. Zimmerman Brush Co., 455 U.S. 422, 443 (1982) (Powell, J., concurring in judgment) (joined by Rehnquist, J.) (expressing concern about majority opinion's "broad pronouncements on the law of procedural due process" and "potential implications of the Court's expansive due process analysis"); Vitek v. Jones, 445 U.S. 480, 500-01 (1980) (Stewart, J., dissenting) (joined by Rehnquist, J.) (since case is moot, Court should vacate judgment and remand to district court with directions to dismiss).

64. 450 U.S. 621,633 (1981) (Rehnquist, J., concurring).

65. Id. at 624-26. The owners sought damages in "inverse condemnation," id. at 626; see United States v. Clarke, 445 U.S. 253, 257 (1980) (inverse condemnation "a shorthand description of the manner in which a landowner recovers just compensation for a taking of his property when condemnation proceedings have not been instituted").

66. 450 U.S. at 633-36 (Rehnquist, J., concurring).

67. See id. at 636-61 (Brennan, J., dissenting); id. at 633-34 (Rehnquist, J., concurring) (indicating agreement with dissent except for Brennan's belief that a final judgment occurred below).

68. 24 Cal. 3d 266, 598 P.2d 25, 157 Cal. Rptr. 372 (1979), aff'd, 447 U.S. 255 (1980) (Powell, J.) (unanimous decision). Brennan claimed that the California Court of Appeals had expressly relied on Agins in deciding San Diego Gas. 450 U.S. at 638-39. The California Supreme Court did not review the lower court's treatment of Agins. Id. at 639.

69. The California court clearly intended to restrict the owner of property affected by excessive police power regulations to the nonmonetary remedies of declaratory judgment or mandamus. $24 \mathrm{Cal}$. 3d at 278, 598 P.2d at 32, 157 Cal. Rptr. at 379. Its theory for doing this, however, was far from clear. While the court attempted to reconcile the restriction with existing just compensation clause precedents, id. at 274, 598 P.2d at 29, 157 Cal. Rptr. at 376, it emphasized the policy considerations 
lack a valid claim to monetary compensation when ordinances inflict a temporary loss on them, since the only remedial "stick" in their bundle of state-defined property rights is that of invalidation.

Rehnquist's concurring remarks indicate that, in contrast to his position on due process property, he would not permit a state to define just compensation property in a way that would defeat an owner's claim to compensation..$^{70}$ Holders of just compensation property are thus provided a kind of constitutional protection against state interference which Rehnquist denies to holders of due process property. ${ }^{71}$

\section{The Levels of Protection Afforded by the Due Process and Just Com- pensation Requirements}

Having found a property interest, Rehnquist has regularly intervened to protect the holders of just compensation property from adverse government action but has found that holders of due process property are entitled to no greater protections than those the government has already provided. Rehnquist joined the majority opinion in Mathews v. Eldridge, ${ }^{72}$ which set forth a balancing test to determine what process is due. ${ }^{73}$ Rehnquist's balancing typically results in finding that the procedures already provided by the government satisfy the requirements of due process. Sometimes Rehnquist minimizes the effects of the adverse state action on the individual, ${ }^{74}$ and sometimes he finds adequate the current procedures

that justified its limitation of landowner's remedies. Id. at 275-78, 598 P.2d at 29-32, 157 Gal. Rptr. at $376-79$.

70. Rehnquist's concurrence in San Diego Gas should not be overinterpreted. The California Supreme Court decision in Agins v. City of Tiburon, on which the case turned, is difficult to interpret. Compare 450 U.S. at 639 (Brennan, J., dissenting) (California Supreme Court's Agins decision held that excessive exercise of the police power could not, as a matter of federal constitutional law, constitute compensable taking) with id. at $628 \mathrm{n.8}$ (Blackmun, J.) (contrary to dissent's argument, Agins merely limited remedy, not underlying claim). Moreover, since Rehnquist did not actually join the dissenters, we do not know precisely which of their views he shares.

71. The federal law involved in due process cases like Arnett $v$. Kennedy creates the property interest and the procedural limitation at the same time. In just compensation contexts, however, the limitation is often imposed some time after the creation of the property interest. A precise analogue between the due process and just compensation cases is therefore impossible. Nonetheless, a state might effect a limitation on remedies for unconstitutional exercises of police power through its definition of property: Owners would hold their property subject to the limitation that they could only obtain invalidation, not monetary damages, for an excessive exercise of the police power. The limitation would in this formulation be closely analogous to the government's attempt to define Kennedy's property so as to entitle him only to the procedures the government chose to provide.

72. 424 U.S. 319 (1976) (Powell, J.).

73. Justice Powell identified three factors that courts must take into account in determining what process is due:

First, the private interest that will be affected by the official action; second, the risk of an erroneous deprivation of such interest through the procedures used, and the probable value, if any, of additional or substitute procedural safeguards; and finally, the Government's interest, including the function involved and the fiscal and administrative burdens that the additional or substitute procedural requirement would entail.

Id. at 335 .

74. See, e.g., Mackey v. Montrym, 443 U.S. 1, 11-12 (1979) (Burger, C.J.) (joined by Rehn- 
given the costs of the alternatives, ${ }^{78}$ but in either event he holds for the government. ${ }^{78}$ This predilection decreases the value of due process property since the value of property depends significantly upon the procedures available to protect it.

Rehnquist dissented in the important just compensation case of Penn Central Transportation Co. v. New York City. ${ }^{77}$ The owners of Grand Central Terminal claimed that the application of New York City's Landmarks Preservation Law, ${ }^{78}$ which prohibited them from building a multi-story office building above the terminal, was a taking that required just compensation. ${ }^{79}$ Justice Brennan held that although application of the law reduced the value of the property, it was not a taking, since the government had interfered neither with the owners' primary expectations regarding use nor with their ability to obtain a "reasonable return" on their investment. ${ }^{80}$

Rehnquist maintained that Penn Gentral's property had been taken, since it was no longer free to use its land and "air rights" in any way consistent with the broad boundaries of New York City's zoning. ${ }^{81}$ Moreover, the ordinance did not fit into what Rehnquist claimed were the only two exceptions to the rule that the government must compensate owners when it has reduced the value of their property by valid regulation under the police power. ${ }^{82}$

Though Rehnquist was in the minority in Penn Central, his views on

quist, J.) (though driver's interest in continued possession and use of license is substantial, statute providing for deprivation without hearing has only minor impact on that interest, since post-suspension hearing is immediately available); Goss y. Lopez, 419 U.S. 565, 587 (1975) (Powell, J., dissenting) (joined by Rehnquist, $J$.) (even assuming deprivation of a protected property interest, deprivation not of constitutional dimensions).

75. See, e.g., Greene v. Lindsey, 456 U.S. 444, 459-60 (1982) (O'Connor, J., dissenting) (joined by Rehnquist, J.) (notice by mail to public housing tenants not likely to be superior to notice by posting on door); Parratt v. Taylor, 451 U.S. 527, 543 (1981) (Rehnquist, J.) (impractical in cases of negligent deprivation for state to provide predeprivation hearing); Board of Curators, Univ. of Mo. v. Horowitz, 435 U.S. 78, 84-85 (1978) (Rehnquist, J.) (even assuming protected property interest, state university has provided adequate procedures before dismissing student); Memphis Light, Gas \& Water Div. v. Craft, 436 U.S. 1, 30 (1977) (Stevens, J., dissenting) (joined by Rehnquist, J.) (due process clause satisfied when state's procedures give citizen fair notice and procedural redress that is adequate when invoked by counsel).

76. One leading commentator claims that Rehnquist strongly favors the government over the individual. Shapiro, supra note 1 , at 294 . While this would explain Rehnquist's position in the due process cases, it cannot explain his stance in the Court's recent just compensation cases, see infra pp. 554-55, all of which have been decided since Shapiro's article was published. Shapiro himself admits that Rehnquist often votes against the government in antitrust and labor-relations cases. Shapiro, supra note 1 , at 294 n.3.

77. 438 U.S. 104 (1978) (Brennan, J.).

78. New York City ADMin. CoDE ch. 8-A (1976).

79. 438 U.S. at 122.

80. Id. at $135-38$.

81. Id. at $142-44$ (Rehnquist, J., dissenting).

82. The ordinance neither prohibited a nuisance nor applied across a broad range of land to secure a reciprocity of advantage for all those affected. Id. at 144-50. 
the scope of protection that the just compensation clause provides have been influential. He wrote the majority opinion in the Court's most important just compensation case after Penn Central, Kaiser Aetna v. United States. ${ }^{83}$ In the most recent case raising a substantial just compensation issue, United States $v$. Security Industrial Bank, ${ }^{84}$ Rehnquist devoted virtually half of his majority opinion to dicta arguing that retroactive application of a federal bankruptcy statute would effect a taking. ${ }^{85}$

Rehnquist's general willingness to invoke the just compensation norm to require the government to pay compensation for property whose value it has reduced contrasts markedly with his reluctance to invoke the due process norm to require the government to provide greater procedural protections when wholly depriving citizens of jobs, welfare benefits, and other important interests. His analysis tends to secure the expectations of holders of old property, such as those in Penn Central, who expected that the government could not prohibit them from developing their property to the fullest extent permitted by prior law without providing compensation, or those in Kaiser Aetna, who expected (particularly since they had invested substantial amounts of money in their property) to have the right to exclude others. His due process analysis renders more uncertain the expectations involving "new property," such as the government employee's expectation in Bishop $v$. Wood that he could be deprived of his job only "for cause" or the expectation of a welfare candidate that he will be denied benefits only after a hearing. ${ }^{86}$ Section III considers how these differences might be explained.

\section{Constitutionalizing a Social Vision}

Some of the obvious explanations of Rehnquist's differential treatment of due process and just compensation property will not suffice. Just compensation property is not always more important to the individual holding it than is due process property. ${ }^{87}$ The difference cannot be adequately explained in terms of Rehnquist's attempt to reintroduce state sovereignty as a functioning legal limitation on federal legislative power, ${ }^{88}$ nor by

83. 444 U.S. 164 (1979); see supra pp. 546-548 (discussing Kaiser Aetna).

84. 103 S. Ct. 407 (1982).

85. Id. at $410-12$.

86. See Peer v. Griffeth, 445 U.S. 970 (1980) (Rehnquist, J., dissenting from denial of certiorari) (concern that Goldberg $v$. Kelly pretermination evidentiary hearing not be extended to applicants for welfare).

87. Compare Loretto v. Teleprompter Manhattan CATV Corp., 102 S. Ct. 3164, 3169 (1982) (Marshall, J.) (joined by Rehnquist, J.) (property taken is space on apartment building occupied by about 35 feet of one-half inch cable and two 4" 4 " 1 4" metal braces) with Kelly v. Wyman, 294 F. Supp. 893, 899-900 (S.D.N.Y. 1968) (detailing plight of terminated welfare claimants), affd sub nom, Goldberg v. Kelly, 397 U.S. 254 (1970).

88. For a discussion of Rehnquist's interpretation of federalism, sec Powell, supra note 1, at 
Rehnquist's "interpretivist" claim that judges should limit themselves to constitutional language and the intent of the Framers in interpreting constitutional clauses. $^{89}$

The distinction between "old" and "new" property is, however, relevant, ${ }^{90}$ though in a different manner than first appears. The common law's longstanding protection of "old property" may seem to render more reasonable the expectations connected with it in comparison to the expectations of a holder of "new property." Given Rehnquist's emphasis on

1322-31. Were federalism the crucial variable in the just compensation context, for example, we would expect Rehnquist to be more tolerant of state (and perhaps local) activities affecting property (including state definitions of property) than he would be of federal activities. Moreover, given Rehnquist's rejection of the doctrine that the 14th Amendment applies the Bill of Rights with equal force to states and the federal government, see First Nat'I Bank v. Bellotti, 435 U.S. 765, 823 (1978) (Rehnquist, J., dissenting) (First Amendment has limited application to states), we would expect him to apply the just compensation requirement of the Fifth Amendment with less stringency to state activities. Yet Rehnquist is no more willing to permit a state (or local) government to affect property in ways that infringe on private property rights than he is willing to permit the federal government to do so. Compare Kaiser Aetna v. United States, 444 U.S. 164 (1979) (Rehnquist, J.) (federal government's attempt to compel right of access to private pond constitutes taking) with Loretto v. Teleprompter Manhattan CATV Corp., 102 S. Ct. 3164 (1982) (Marshall, J.) (joined by Rehnquist, J.) (New York state law authorizing installation of cable TV facilities on private property constitutes constitutionally compensable taking) and Penn Cent. Transp. Co. v. New York City, 438 U.S. 104, 142-44 (1978) (Rehnquist, J., dissenting) (application of New York City's Landmarks Preservation Act constitutes taking of Penn Central's property). Rehnquist has also found both state and federal actions not to constitute takings. See Texaco, Inc. v. Short, 454 U.S. 516, 530 (1982) (Stevens, J.) (joined by Rehnquist, J.) (Indiana law providing for lapse of mineral owners' property interests held not to constitute taking); Andrus v. Allard, 444 U.S. 51, 64-68 (1979) (Brennan, J.) (joined by Rehnquist, J.) (federal law prohibiting party from selling Indian artifacts acquired before passage of law held not to constitute taking).

89. See Rehnquist, The Notion of a Living Constitution, 54 TEx. L. REv. 693, 695, 698, 704 (1976) (constitutional analysis should be based on values derived from language of Constitution and intent of Framers). Any interpretivist account of the just compensation clause encounters the dual difficulty that there is little historical evidence bearing on its meaning and that scholars dispute the significance of what evidence there is. Stoebuck argues that no researcher has discovered an English or American colonial decision rendered prior to 1789 that holds compensation required for a taking. Stoebuck, A General Theory of Eminent Domain, 47 WASH. L. REv. 553, 575 (1972). Although there was a legislative practice of awarding compensation in some cases, there is little agreement on the scope of the right to compensation or the theory under which legislatures awarded it. Compare id. at 584 (theory of just compensation was that no citizen should be expected to bear more than just share of the cost of government) with Sax, Takings and the Police Power, 74 YALE L.J. 36, 54-60 (1964) (just compensation intended as guarantee against unfair or arbitrary government). Stoebuck also argues that the historical sources bearing on the meaning of the just compensation clause made no attempt to define "property." Stoebuck, supra, at 600 . Perhaps because of these difficulties, Rehnquist makes no reference to historical intent in his just compensation opinions.

In at least one case, Penn Cent. Transp. Co. v. New York City, 438 U.S. 104, 138 (1978) (Rehnquist, J., dissenting), Rehnquist attempts a mode of analysis-one based on the "literal meaning" of "property," "taken," and "just compensation"- that would be consistent with his interpretivist theory. But the analysis relies on more than the mere "literal meaning" of the relevant terms. In discussing whether Penn Central's property has been "taken," for example, Rehnquist states: "While the term 'taken' might have been narrowly interpreted to include only physical seizures of property rights, 'the construction of the phrase has not been so narrow." Id. at 143 (citation omitted). Rehnquist thus relies on something beyond the "literal meaning" of "taken," i.e., past Supreme Court precedent construing the word more broadly, to reach his conclusion.

90. See supra pp. 543-44 (discussing "old" and "new" property).

91. For example, the expectations of an employee claiming a property interest in a job may seem 
the primacy of positive state law in defining property, ${ }^{92}$ however, the fact that the common law recognized a particular property interest does not relieve the owner of the obligation of establishing that it is recognized, and that his expectations are thus reasonable, under current state law.

The distinction between old and new property illuminates Rehnquist's theory of property insofar as his treatment of these kinds of property reasserts the property rights recognized at common law, and is thus compatible with what some economists and legal theorists argue is an efficient assignment of property rights. The remainder of this Note explores the connection between Rehnquist's theory of property and economic theory.

For some economic and legal theorists the unfettered operation of the market is the ultimate guarantor of economic efficiency. ${ }^{93}$ These theorists, who are often labeled "conservatives," seek an assignment of property rights that provides the correct incentives for those holding productive resources. ${ }^{24}$

One set of efficiency considerations pertains to what this Note has called just compensation property. An efficient system induces those who control resources to invest in their development. Legal rules securing property owners' expectations that they will be able to exclude others, ${ }^{95}$

quite unreasonable in the context of a society which has traditionally defined employment as terminable "at will" unless they are clearly established in state law. See Blades, Employment at Will us. Individual Freedom: On Limiting the Abusive Exercise of Employer Power, 67 Colum. L. Rev. 1404, 1416 (1967).

92. See supra note 30 .

93. Economists and practitioners of the economic analysis of law employ a number of different efficiency-related notions. See, e.g., W. BAUmol, Economic TheORY and Operations ANalysis 502-03, 526-31 (4th ed. 1977) (discussing productive efficiency, the Pareto criterion, and the Kaldor criterion); Coleman, Efficiency, Utility, and Wealth Maximization, 8 Horstra L. REv. 509, 512 (1980) (identifying use of productive efficiency, Pareto criteria, and Kaldor-Hicks notions in current literature). Posner has introduced a fourth efficiency-related notion, "wealth maximization." Posner, Utilitarianism, Economics, and Legal Theory, 8 J. Legal Stud. 103 (1979). But see Coleman, supra, at 520-26 (wealth maximization not an efficiency criterion). Rehnquist's position is most compatible with the productive or allocative sense of efficiency, according to which a system is efficient if it maximizes the productive use of resources, both human and non-human, see W. BAUMOL, supra, at 502-03.

For examples of the argument that markets promote efficiency, see F. KNIGHT, The Ethics of Competition, in THE ETHICs of CoMPETTITON AND OTHER ESSAYS 66-75 (1935) (market competition promotes efficiency); A. Kronman \& R. POSnER, The Economics of Contract Law 2 (1979) (markets maximize wealth of society).

94. If there were no transaction costs, any initial assignment of property rights would produce an efficient outcome. See Coase, The Problem of Social Cost, 3 J. L. \& EcoN. 1, 8 (1960). The prevalence of transaction costs leads some to suggest that private property is the most efficient allocation of property rights. See Demsetz, Toward a Theory of Property Rights, 57 AM. EcoN. REv., PAPERS \& Proc. 347, 356-57 (1967) (arguing that private ownership has lower transaction costs than communal ownership and is thus more efficient); see also R. Posner, Economic ANalysis of LAw 54 (2d ed. 1977) (property rights impart correct incentives to producc).

95. With communal ownership, individuals can reap benefits from use of the resource while avoiding the costs they impose on others. See, e.g., R. POSNER, supra note 94, at 28; Demsetz, supra note 94 , at 354-55. The solution is claimed to be private control, with individual owners bearing the 
and that the government will not interfere with the lawful use of their property without compensating them, ${ }^{96}$ induce them to invest and thus promote efficiency. In the case of employment and welfare benefits, ${ }^{97}$ freemarket economists argue that employers should be able to discharge employees "at will" in the absence of explicit contractual terms to the contrary. ${ }^{98}$ The employer's "normal right of discharge" should be unfettered by considerations of due process since the employer is in the best position to direct resources to maximize production ${ }^{29}$ and since such terms motivate employees to work conscientiously ${ }^{100}$ and to allocate their own "human capital" effectively. ${ }^{101}$ The efficiency argument with respect to welfare benefits similarly argues for minimal due process rights. ${ }^{102}$

The role that these economic and legal theorists attribute to efficiency in evaluating legal institutions should be, and has been, challenged. The notion of "efficiency" is itself used in many different ways, ${ }^{103}$ and there is disagreement over which institutions best promote it. ${ }^{104}$ The proper role

benefits and the full costs of use of the resource. See, e.g., R. POSNER, supra note 94, at 49 (right to exclude in property rights "optimize[s] resource use"); Demsetz, supra note 94, at 356 (drawing same connection).

96. For government to take land without compensation would generate inefficiencies similar to those described supra note 95 since the property owner would be unable to exclude the government. As long as the government pays the owner the full value of his land, the transaction is efficient. See $R$. POSNER, supra note 94, at 41 (requirement that condemnor compensate owner for value of land taken promotes efficiency by ensuring that value of land to condemnor exceeds its value to present owner).

97. These benefits figure prominently in recent due process cases. See, e.g., Bishop v. Wood, 426 U.S. 341 (1976) (public employment); Goldberg v. Kelly, 397 U.S. 254 (1970) (welfare benefits).

98. For discussions of the application of freedom of contract to the employment context, see, e.g., D. Ewing, Freedom Inside the Corporation 32-35 (1977); Blades, supra note 91, at 1416-21.

99. See, e.g., F. KNIGHT, supra note 93, at 61 ("For efficiency in the production of goods a large concentration of authority is necessary."); Blades, supra note 91, at 1428 (employer's prerogative to make independent, good-faith judgments about employees important to success of business in free enterprise system).

100. See M. Friedman \& R. Friedman, Free to Choose 243-44 (1980) (attributing inefficiency of civil service system to job security it provides employees).

101. "Human capital" is the employee's skill and training. See generally G. BECKER, ECONOMIC THEORY 160 (1971) (treating human labor as capital on grounds that large part of wages and salaries attributable to investment in humans). Since the employee can "invest" in her human capital by obtaining additional education or on-the-job training, but is unlikely to do so without changing jobs, "at will" employment encourages the proper investments and adjustments in human capital. See G. Becker, Human Capitai, 72 (2d ed. 1975) (emphasizing education, on-the-job training, and changing jobs and locations as important ways of "investing in human capital").

102. The rationale for minimal welfare benefits, and thus impliedly for minimal protection of such benefits, emphasizes that welfare recipients have little incentive to perform productive work. See, e.g., M. Friedman \& R. Friedman, supra note 100, at 119; R. POSNER, supra note 94, at 352. Welfare benefits have historically been designed to compare unfavorably to almost any available wage. See F. Piven \& R. Cloward, Regulating the Poor 32-36 (1971).

103. See supra note 93.

104. For views opposed to those of the economists and legal theorists being considered, see, e.g., 1 K. Marx, Capital 628-40 (1967) (1st ed. 1867) ("reserve army" of unemployed workers a necessary condition of capitalist mode of production); D. SCHWEICKART, CAPITALISM OR WORKER CoNTROL? 70-98 (1980) (significant inefficiencies generated by private ownership of means of production). 
of efficiency considerations-as opposed, say, to matters of justice-is also disputed. ${ }^{205}$

More fundamentally, if less obviously, the compatibility of Rehnquist's views with what some economists and legal theorists regard as an efficient system of property rights ${ }^{106}$ suggests the sharing of a social vision of a world in which those persons without capital (other than their own labor power) must labor for those people with capital. The state must provide security for those who control capital in order to induce them to invest. In order to ensure that holders of capital can allocate labor efficiently, and in order to encourage laborers to accept this distribution or to become holders of capital themselves, the state must not provide security to those without capital. To the extent Rehnquist's theory of property, as revealed in

Even assuming that efficiency is a value, and that it may be furthered by property rights of the sort advocated by the theorists being considered, there is the further question whether judges should pursue efficiency. See Coleman, supra note 93, at 550 (argument that judicial behavior should be structured by efficiency considerations requires further theory of institutional competence); Dworkin, $I s$ Wealth a Value?, 9 J. LEGAL STud. 191, 195-96, 216-17 (1980) (normative aspect of economics of law requires theory of institutional competence of judges to pursue efficiency).

105. Rawls, for example, clearly subordinates considerations of efficiency to those of justice when he states: "Justice is the first virtue of social institutions, as truth is of systems of thought. A theory however elegant and economical must be rejected or revised if it is untrue; likewise laws and institutions no matter how efficient and well-arranged must be reformed or abolished if they are unjust." J. RAWLS, A TheORY OF JUSTICE 3 (1971).

One should note the distributional consequences of Rehnquist's analysis of property. The just compensation clause substantially affects only those who have property that is worth being taken by the government. The language of Rehnquist's just compensation opinions, moreover, suggests that he is especially concerned that the government not interfere with the expectations of those who have made substantial investments. See, e.g., PruneYard Shopping Center v. Robins, 447 U.S. 74, 84 (1980) (Rehnquist, J.); Kaiser Aetna v. United States, 444 U.S. 164, 167, 176 (1979) (Rehnquist, J.). Though the due process clause protects property of all forms, the real expansion of protection that began with Goldberg v. Kelly, 397 U.S. 254 (1970), concerned those forms of property held principally by poor and working persons. See generally S. BREYER \& R. STEWART, supra note 14, at 596 (even before recent trend of extending due process protection to interests not recognized by common law, courts extended procedural safeguards to protect groups such as licensed professionals).

106. The fact of compatibility is, in itself, interesting and significant. Dworkin, supra note 104, argues that a mere correlation between the decisions judges have made in a certain area of law and the decisions that a judge explicitly seeking to maximize social wealth would have made does not advance our understanding of the legal process to an important degree. Id. at 221. Dworkin thinks it preposterous to regard social wealth as a component of social value and implausible to believe that the pursuit of social wealth is an effective means of achieving some other component of social value. He therefore believes that the correlation between a judge's decisions and decisions that an explicitly wealth-maximizing judge would make lacks explanatory power because it has no connection with a plausible theory of the judge's motivation. Id. at 220-22. Dworkin thus attempts to argue from the falsity of a normative claim to the implausibility of a descriptive claim. This form of argument is unsatisfactory. A judge might falsely believe that maximizing the productive use of resources, for example, is a component of social value, yet seek to maximize such use under the mistaken belief that it is a component of social value. Moreover, even if maximizing the productive use of resources is not an element of social value, it does not seem implausible to believe that it is an effective means of promoting something else-for example, utility-that is an element of social value. In any case, it seems more plausible than the analogous belief about maximizing social wealth, understood as conceptually tied to the prices people are willing to pay for goods and resources, id. at 191. 
the due process and just compensation clause decisions he has written and joined, is informed by this social vision and set of assumptions, it gives constitutional significance to a quite particular and disputable view of the world and of the possibilities for relations between people.

-Stephen J. Massey 